\title{
ESTIMATION OF THE CRANIAL CAPACITY IN DRY HUMAN SKULL
} BONES

\section{Sangeetha K. *1, Sathya Murthy B ${ }^{2}$.}

${ }^{1}$ Assistant Professor, Department of Anatomy, Rajarajeshwari Medical College and Hospital, Bengaluru, Karnataka, India.

*2 Professor, Department of Anatomy, Rajarajeshwari Medical College and Hospital, Bengaluru, Karnataka, India.

\section{ABSTRACT}

Introduction: Cranial capacity is a measure of the volume of the interior of the skull of those vertebrates who have both a skull and a brain. Cranial capacity is used as a rough indicator of the size of brain. Cranial capacities like several bodily dimensions are affected by environmental, ecological, biological, geographical, racial, gender and age factors.

Aim: The aim of the study is to measure and calculate cranial capacity by direct and calculated methods and to classify the skull under different subtypes.

Materials and Methods: The study will constitute 100 dried human skull bones belonging to both sexes in the Department of Anatomy, Rajarajeswari medical college, Bengaluru.

Results: The average cranial capacity by using direct method is $1275.33 \mathrm{cc} \pm 124.68 \mathrm{cc}$ in male skulls and $1213 \mathrm{cc}$ $\pm 138.66 \mathrm{cc}$ in female skulls and by calculated method is $1344.10 \mathrm{cc} \pm 106.62 \mathrm{cc}$ in male skulls and $1276.26 \mathrm{cc} \pm$ $68.72 \mathrm{cc}$ in female skulls respectively.

Conclusion: The mean cranial capacities of male skulls were higher than that of female skulls that tends to agree with similar studies conducted earlier. Thus, the cranial capacity of the male skulls is $5-15 \%$ higher than the female skulls.

KEY WORDS: Cranial capacity, linear measurement, packing method, Lee-Pearson formula

Address for Correspondence: Dr.Sangeetha K, Assistant professor, Department of Anatomy, Rajarajeswari Medical College \& Hospital, Kambipura, Kumbalgodu, Mysore-Bengaluru road, Bengaluru, Karnataka, India. E-Mail: sangeethak794@gmail.com

Access this Article online

Quick Response code

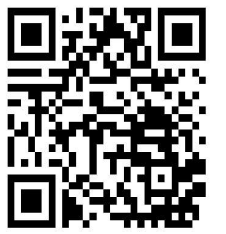

DOI: $10.16965 /$ ijar.2018.145

Journal Information

\section{International Journal of Anatomy and Research}

ICV for 2016 ISSN (E) 2321-4287 | ISSN (P) 2321-8967

90.30

https://www.ijmhr.org/ijar.htm

DOI-Prefix: https://dx.doi.org/10.16965/ijar

\section{(cc) ET-No-Bi}

\section{Article Information}

Received: 13 Feb 2018

Peer Review: 14 Feb 2018

Revised: None
Accepted: 05 Apr 2018
Published (O): 05 May 2018
Published (P): 05 May 2018

\section{INTRODUCTION}

Cranial capacity is a measure of the volume of the interior of the skull (also called the braincase or brainpan) of those vertebrates who have both a skull and a brain. Cranial volume is often used as a general estimate for the size of a vertebrate's brain. Cranial capacity is used as a rough indicator of the size of brain. Craniometric study is an important fraction of anthropometry that can be employed in the determination of cranial study of an individual. Cranial capacities like several bodily dimensions are affected by environmental, ecological, biological, geographical, racial, gender and age factors. The cranial capacity has been used indirectly to reflect the volume of the brain and to predict the mental ability. It is also useful in the field of forensic anthropology and pediatrics as an indicator of skull development in both male and female individuals [1]. Skulls may be classified 
according to their cranial capacities as Microcephalic: Cranial capacity < 1350 cc, Mesocephalic: Cranial capacity $1350 \mathrm{cc}$ to $1450 \mathrm{cc}$ Megacephalic: Cranial capacity $>1450$ ccs [2]. This information is useful in correlating cranial capacity with other cranial measurements and in studies of primate phylogeny. Medically, an analysis of cranial capacity exposes another aspect of growth and development and permits critical evaluation of unusually large, small, or misshapen crania [3]. These skeletons are from living primates some are from the fossil records. For this reason physical anthropologists have become specialists in skeletal anatomy [4]. In Forensic science, anthropologists are often directly involved in the analysis of archeological and fossilized skeletal remains. Using skeletal remains, the anthropologists can also estimate a person's stature and general body proportion in life. In addition, skeletal remains help in the determination of a person's racial back ground [5].

AIM: The aim of the study is to measure and calculate cranial capacity by direct and calculated methods and to classify the skull under different subtypes.

\section{MATERIALS AND METHODS}

Source of Data: The study constituted 100 dried human skulls belonging to both sexes in the Department of Anatomy from the first year students (2013-15 batches), Raja Rajeshwari Medical college, Bengaluru. Approval from the institutional ethics committee was taken for the study. The sex of the skulls was determined by examining the superciliary arches, mastoid process, frontal and parietal eminence, muscular ridges. Materials used were spreading calipers, Measuring tape, Channa dal to fill into the skull, Two liters measuring cylinder to measure the quantity, Rubber ring as a bed to place the skull during the procedure, Cotton to plug the foramina.

\section{METHODS OF COLLECTION OF DATA:}

Linear Measurement: The cranial volume is calculated by using three principle dimensions of the cranium: 1 . Maximum cranial length (L): One point at the glabella and another point at the inion are taken and the maximum cranial length is measured using spreading caliper.
2. Maximum cranial breadth (B): This is measured using spreading caliper, distance between two parietal eminences above the zygomatic arches (Biparietal diameter). 3. Basion-bregmatic height $(\mathrm{H})$ : One point is taken at the basion and another point on the bregma and the height is measured using measuring tape. Usually the measurement should be made at least 3 times and the average of the three is considered for calculations. Using the following formula derived by Lee- Pearson the cranial volume can be computed- Males: $524.6+0.000266 \times \mathrm{LxBxH} \&$ Females: $812+0.000156 \times \mathrm{LxBxH}$.

Packing/Filling Method: This method is widely used for determining the cranial volume of the skull, where the interior of the skull is packed with the filling materials and then measured. Packing materials used in our study is channa dal. First all the foramina of the skull are plugged with cotton. Then the skull is placed over the rubber ring with frontal end at a lower level. After all the foramina were packed by cotton, a large funnel is placed into the foramen magnum. Now channa dal is poured into the skull with a forward tilt. Again skull is tilted to right and left to fill the dal upto foramen magnum, and pressed with thumb gently backward and downwards into occipital region, and then the space left is finally filled with dal upto the level of foramen magnum and smoothed off without pressure. The filled in channa dal into the skull were poured into the 2 litres graduated measuring jar and the readings were taken. The process was repeated to cross check the accuracy of measurements.

Statistical Methods: Descriptive and inferential statistical analysis has been carried out in the present study. Analysis of variance (ANOVA) has been used to find the significance of study parameters between three or more groups of skulls and Student t test (two tailed, dependent) has been used to find the significance of study parameters on continuous scale within each group. Chi-square/ Fisher Exact test has been used to find the significance of study parameters on categorical scale between two or more groups. Pearson correlation between study variables is performed to find the degree of relationship $[6,7]$. 


\section{RESULTS}

Table 1: Gender distribution of skulls studied.

\begin{tabular}{|c|c|c|}
\hline Gender & No. of skulls & $\%$ \\
\hline Male & 60 & 60 \\
\hline Female & 40 & 40 \\
\hline Total & 100 & 100 \\
\hline
\end{tabular}

Table 2: Length $(\mathrm{mm})$ distribution of skulls studied.

\begin{tabular}{|c|c|c|c|}
\hline \multirow{2}{*}{ Length $(\mathrm{mm})$} & \multicolumn{2}{|c|}{ Gender } & \multirow{2}{*}{ Total } \\
\cline { 2 - 4 } & Male & Female & \\
\hline$<150$ & $1(1.7 \%)$ & $3(7.5 \%)$ & $4(4 \%)$ \\
\hline $150-160$ & $1(1.7 \%)$ & $6(15 \%)$ & $7(7 \%)$ \\
\hline $161-170$ & $18(30 \%)$ & $11(27.5 \%)$ & $29(29 \%)$ \\
\hline $171-180$ & $28(46.7 \%)$ & $16(40 \%)$ & $44(44 \%)$ \\
\hline $181-190$ & $12(20 \%)$ & $4(10 \%)$ & $16(16 \%)$ \\
\hline Total & $60(100 \%)$ & $40(100 \%)$ & $100(100 \%)$ \\
\hline
\end{tabular}

Table 3: Breadth (mm) distribution of skulls studied.

\begin{tabular}{|c|c|c|c|}
\hline \multirow{2}{*}{ Breadth $(\mathrm{mm})$} & \multicolumn{2}{|c|}{ Gender } & \multirow{2}{*}{ Total } \\
\cline { 2 - 3 } & Male & Female & \\
\hline$<120$ & $0(0 \%)$ & $3(7.5 \%)$ & $3(3 \%)$ \\
\hline $120-130$ & $28(46.7 \%)$ & $19(47.5 \%)$ & $47(47 \%)$ \\
\hline $131-140$ & $27(45 \%)$ & $15(37.5 \%)$ & $42(42 \%)$ \\
\hline $141-150$ & $5(8.3 \%)$ & $3(7.5 \%)$ & $8(8 \%)$ \\
\hline Total & $60(100 \%)$ & $40(100 \%)$ & $100(100 \%)$ \\
\hline
\end{tabular}

Table 4: Height $(\mathrm{mm})$ distribution of skulls studied.

\begin{tabular}{|c|c|c|c|}
\hline \multirow{2}{*}{ Height $(\mathrm{mm})$} & \multicolumn{2}{|c|}{ Gender } & \multirow{2}{*}{ Total } \\
\cline { 2 - 3 } & Male & Female & \\
\hline$<120$ & $1(1.7 \%)$ & $2(5 \%)$ & $3(3 \%)$ \\
\hline $120-130$ & $13(21.7 \%)$ & $18(45 \%)$ & $31(31 \%)$ \\
\hline $131-140$ & $44(73.3 \%)$ & $20(50 \%)$ & $64(64 \%)$ \\
\hline $141-150$ & $2(3.3 \%)$ & $0(0 \%)$ & $2(2 \%)$ \\
\hline Total & $60(100 \%)$ & $40(100 \%)$ & $100(100 \%)$ \\
\hline
\end{tabular}

Table 5: Comparison of Measurements in male and female skulls studied.

\begin{tabular}{|c|c|c|c|c|}
\hline \multirow{2}{*}{ Measurements } & \multicolumn{2}{|c|}{ Gender } & \multirow{2}{*}{ Total } & \multirow{2}{*}{ P value } \\
\cline { 2 - 3 } & Male & Female & & \\
\hline Length $(\mathrm{mm})$ & $173.92 \pm 8.17$ & $169.27 \pm 10.22$ & $172.06 \pm 9.28$ & $0.013^{*}$ \\
\hline Breadth $(\mathrm{mm})$ & $131.82 \pm 6.24$ & $131.33 \pm 7.18$ & $131.62 \pm 6.60$ & 0.717 \\
\hline Height $(\mathrm{mm})$ & $133.48 \pm 4.99$ & $130.96 \pm 5.41$ & $132.47 \pm 5.28$ & $0.019^{*}$ \\
\hline
\end{tabular}

Table 6: Direct cranial volume $(\mathrm{ml})$ distribution of skulls studied.

\begin{tabular}{|c|c|c|c|}
\hline \multirow{2}{*}{$\begin{array}{c}\text { Direct cranial } \\
\text { volume }(\mathrm{ml})\end{array}$} & \multicolumn{2}{|c|}{ Gender } & \multirow{2}{*}{ Total } \\
\cline { 2 - 3 } & Male & Female & \\
\hline Microcephalic & $38(63.3 \%)$ & $37(92.5 \%)$ & $75(75 \%)$ \\
\hline Mesocephalic & $19(31.7 \%)$ & $2(5 \%)$ & $21(21 \%)$ \\
\hline Megacephalic & $3(5 \%)$ & $1(2.5 \%)$ & $4(4 \%)$ \\
\hline Total & $60(100 \%)$ & $40(100 \%)$ & $100(100 \%)$ \\
\hline
\end{tabular}

Table 7: Calculated cranial volume (ml) distribution of skulls studied.

\begin{tabular}{|c|c|c|c|}
\hline \multirow{2}{*}{$\begin{array}{c}\text { Calculated cranial } \\
\text { volume (ml) }\end{array}$} & \multicolumn{2}{|c|}{ Gender } & \multirow{2}{*}{ Total } \\
\cline { 2 - 3 } & Male & Female & \\
\hline Microcephalic & $32(53.3 \%)$ & $37(92.5 \%)$ & $69(69 \%)$ \\
\hline Mesocephalic & $24(40 \%)$ & $2(5 \%)$ & $26(26 \%)$ \\
\hline Megacephalic & $4(6.7 \%)$ & $1(2.5 \%)$ & $5(5 \%)$ \\
\hline Total & $60(100 \%)$ & $40(100 \%)$ & $100(100 \%)$ \\
\hline
\end{tabular}

Table 8: Comparison of Direct cranial Volume and Calculated Cranial Volume in male and female skulls studied.

\begin{tabular}{|c|c|c|c|c|}
\hline & \multicolumn{2}{|c|}{ Gender } & \multirow{2}{*}{ Total } & P value \\
\cline { 2 - 3 } & Male & Female & & \\
\hline $\begin{array}{c}\text { Direct cranial } \\
\text { volume }(\mathrm{ml})\end{array}$ & $1275.33 \pm 124.68$ & $1213.00 \pm 138.66$ & $1250.40 \pm 133.34$ & $0.021^{*}$ \\
\hline $\begin{array}{c}\text { Calculated cranial } \\
\text { volume }(\mathrm{ml})\end{array}$ & $1344.10 \pm 106.62$ & $1276.26 \pm 68.72$ & $1316.96 \pm 98.74$ & $0.001^{* *}$ \\
\hline
\end{tabular}

Table 9: Testing the significance of Volume $(\mathrm{ml})$ by Direct and Calculated methods.

\begin{tabular}{|c|c|c|c|c|c|}
\hline & Min-Max & Mean \pm SD & Difference & t value & P value \\
\hline $\begin{array}{c}\text { Direct cranial } \\
\text { volume (ml) }\end{array}$ & $850.00-1600.00$ & $1250.40 \pm 133.34$ & - & - & - \\
\hline $\begin{array}{c}\text { Calculated cranial } \\
\text { volume (ml) }\end{array}$ & $1134.13-1941.90$ & $1316.96 \pm 98.74$ & 66.561 & 6.425 & $<0.001 *$ \\
\hline
\end{tabular}

Table 10: Correlations Direct cranial volume with length, breadth, height, Circumference.

\begin{tabular}{|c|c|c|}
\hline Pearson Correlation & r value & P value \\
\hline $\begin{array}{c}\text { Direct cranial volume (ml) v/s } \\
\text { Length (mm) }\end{array}$ & 0.426 & $<0.001^{* *}$ \\
\hline $\begin{array}{c}\text { Direct cranial volume }(\mathrm{ml}) \mathrm{v} / \mathrm{s} \\
\text { Breadth (mm) }\end{array}$ & 0.604 & $<0.001^{* *}$ \\
\hline $\begin{array}{c}\text { Direct cranial volume }(\mathrm{ml}) \mathrm{v} / \mathrm{s} \\
\text { Height }(\mathrm{mm})\end{array}$ & 0.558 & $<0.001^{* *}$ \\
\hline $\begin{array}{c}\text { Direct cranial volume }(\mathrm{ml}) \mathrm{v} / \mathrm{s} \\
\text { Circumference }(\mathrm{mm})\end{array}$ & 0.643 & $<0.001^{* *}$ \\
\hline $\begin{array}{c}\text { Direct Cranial Volume }(\mathrm{ml}) \mathrm{v} / \mathrm{s} \\
\text { calculated }(\mathrm{mm})\end{array}$ & 0.638 & $<0.001^{* *}$ \\
\hline
\end{tabular}

\section{DISCUSSION}

In the present study following observations are done, 6 the mean cranial capacity by using: A) Direct measurement is $1275.33 c c \pm 124.68 c c$ in male skulls and $1213 \mathrm{cc} \pm 138.66 \mathrm{cc}$ in female skulls. B) Calculated method is $1344.10 \mathrm{cc} \pm$ $106.62 \mathrm{cc}$ in male skulls and $1276.26 \mathrm{cc} \pm 68.72 \mathrm{cc}$ in female skulls. Based on overall mean cranial capacity of both sexes by direct method, the skulls could be classified as $63.3 \%$ of male and $92.5 \%$ of female skulls were microcephalic. However, $31.7 \%$ of male and $5 \%$ of female skulls were mesocephalic, while $5 \%$ of male and 
$2.5 \%$ of female skulls were megacephalic.

Thus, based on calculated method, the skulls could be classified as, $53.3 \%$ of male and $92.5 \%$ of female skulls were microcephalic, however, $40 \%$ of male and $5 \%$ of female skulls were mesocephalic and while $6.7 \%$ of male and $2.5 \%$ of female skulls were megacephalic.The skulls used in the present study has a rounded to long shape (dolicocephalic), with a narrow nasal aperture, moderately developed supraorbital ridging, prominent nasal spine, a steeple shaped nasal root, little prognathism and a narrow interorbital distance. The forehead is steep, the chin is prominent, the palate is long and narrow, the cheek bones are not overly prominent and there is a tendency to maxillary protrusion or mandibular retrusion which belongs to the Caucasoid racial group.

In 1995, study of Korean adult cranial capacity done by Young Hawy by Direct/ filling method cranial capacity of male and female $1407+/-$ 107 and $1317+/-117$ which is more than our study may be due to ethnic factor[8].

Manjunath in 2002, estimated cranial volume in 50 dissecting room cadavers (33 males; 17 females) using linear dimensions of the head (using Lee-Pearson's formula) measured with spreading caliper and Todd's head spanner. Following the removal of the calvaria the cranial volume was again estimated using spheroid formula after subtracting the linear dimensions from scalp/soft tissue thickness. The estimated mean cranial volume was as follows: by calculated method/ Lee Pearson's formula: Males: $1152.813 \pm 279.16 \mathrm{cc}$; Females: $1117.82 \pm$ 99.09cc. By spheroid formula: Males-mean: 1169.68 $\pm 239.98 c c ;$;Females-mean 1081 $\pm 111.6 c c$ and the length, breadth, height, circumference similar to our results [9].

In 2007, Acer Usanmaz estimated CC in 1722 years old university students Turkey. They studied 226 male and 140 female health students and found that CC is $1411 \mathrm{cc}$ and $1306 \mathrm{cc}$ respectively. There was significant difference between genders. Their study showed CC is larger in males, results similar to our study [10]. In 2010 Gohiya etal, estimated CC in 20-25 years old population of Madhya Pradesh. They studied 200 males and females by using linear dimensions of head, mean CC in males and Int J Anat Res 2018, 6(2.2):5181-85. ISSN 2321-4287 females $1380 \mathrm{cc}$ and $1189 \mathrm{cc}$ respectively. This study has shown significance difference between male and female population, male being higher than in female, and this result almost similar to our study [11].

In 2011 M.B. Maina measured CC in 150 males and 150 females, aged $18-35$ years using random stratified methods. Linear measurements of $\mathrm{CL}, \mathrm{CH}, \mathrm{HC}$ and width were under taken and their CC significantly higher in male than in females. CL significantly higher in males than in females. The result obtained from this study confirms that $\mathrm{CC}$ higher in males than females. CC of males and females $1442 \mathrm{cc}$ and $1331 \mathrm{cc}$ respectively. Cranial length, height, circumference and width 145and 141, 145 and 141, 564 and 570, 191 and 183 respectively for males and females, this is similar to our study [12].

Ilayperumal etal, in 2011 Sri Lankan, a total of 210 subjects with an age span of 20-23 years were included in the study. The cranial length, breadth and auricular head height of the subjects were recorded using a digital sliding caliper and Todd's head spanner capable of measuring to the nearest $0.01 \mathrm{~mm}$. The cranial capacity was calculated using external dimensions of the skulls (Lee \& Pearson, 1901; Williams et al., 2000). The findings of the study indicated significant sexual differences in the mean cranial capacity (male: $1421.12 \pm 171.69 \mathrm{cc}$, female: $1300.95 \pm 158.18 \mathrm{cc}$ ) similar to our study [13].

Murali Lalwani has conducted study in 2012 about craniometric to study differentiate sex from intracranial volume of dry human skulls. The study was done on 100 male and 60 females. They used dry mustard seed of uniform size to fill the cranium. CC of female 1179 and male 1302 respectively, this is similar to our study [14].

Sadakat Ali, in 2104 conducted a study on adult north Indian human skulls. They studied 112 male and 88 female dry skulls. In their study they used filling and packing method to know the CC which is 1260 and 1164 respectively in male and female similar to our study[15]. Most of the anthropologists while studying crania of various races on the basis of morphological and metrical features have concluded that the population of a country is no more formed by one homogeneous element but instead is constituted by 
Sangeetha K, Sathya Murthy B. ESTIMATION OF THE CRANIAL CAPACITY IN DRY HUMAN SKULL BONES.

\begin{tabular}{|c|c|c|c|}
\hline Authors & $\begin{array}{c}\text { Cranial capacity } \\
\text { (male) }\end{array}$ & $\begin{array}{c}\text { Cranial capacity } \\
\text { (female) }\end{array}$ & Methods used \\
\hline Young Hawi etal 1995- Korea & $1470+/-107$ & $1317+/-117$ & Filing method \\
\hline Manjunath etal 2002 - india & $1152+/-94$ & $1188+/-1188$ & L-P formula \\
\hline Usnawz etal 2007etal - turkey & $1411+/-118$ & $1306+/-162$ & Linear dimension \\
\hline Gohiya etal (2010) India & $1380+/-94$ & $1188+/-75$ & Linear dimension \\
\hline Maina etal, (2011)Nigeria & $14234+/-137$ & $1331+/-201$ & Linear dimension \\
\hline Murali etal, (2012 ) India & $1302+/-108$ & $1179+/-97$ & Filling method \\
\hline Nzotta etal, (2014) Nigeria & $1636+/-109$ & $1632+/-149$ & L-P formula \\
\hline Sadakat etal, (2014) India & $1260+/-75$ & $1164+/-89$ & Filling \& pack \\
\hline Present study & $1275+/-124$ & $1213+/-138$ & Filling method \\
\hline Present study & $1344+/-106$ & $1276+/-68$ & L-P formula \\
\hline
\end{tabular}

heterogeneous elements (Shukla-1966). This explains how there can be a wide range of variation of cranial capacity within a population. The skulls used in the present study has a rounded to long shape (dolicocephalic), with a narrow nasal aperture, moderately developed supraorbital ridges, prominent nasal spine, a steeple shaped nasal root, little prognathism and a narrow interorbital distance. The forehead is steep, the chin is prominent, the palate is long and narrow, the cheek bones are not overly prominent and there is a tendency to maxillary protrusion or mandibular retrusion which belongs to the Caucasoid racial group.

\section{CONCLUSION}

There was a significant difference between genders of head length, head breadth and head height of male compared to female skulls. Thus, cranial capacity of the males is $5-15 \%$ higher than the female skulls. . Therefore, estimating cranial capacity of skull is an undisputable criterion for sex determination from skeletal remains and filling method is more accurate compared to calculated method to measure cranial capacity.

\section{ABBREVIATIONS}

CC- Cranial Capacity

CL- Cranial Length

CB- Cranial Breath

HC- Head circumference

\section{Conflicts of Interests: None}

\section{REFERENCES}

[1]. Hwang Robert jurmain. Introduction to physical anthropology, 2013-14:292.

[2]. A K Dutta. Essentials of Human Anatomy, head and neck, 5thEdn.:3.
[3]. Smithsonian's. The Secret in the Cellar Webcomic, an educational resource from the Written in Bone exhibition, 2009-2011:33-37.

[4]. Pal GP, Bhagwat SS, \& Routal RV. A study of sutural bone in Gujrati (Indian) crania; 1986; 44(1):67-76.

[5]. Krogman WM. The human skeleton in forensic medicine. 23rd Edn. 1973:112-121.

[6]. Sunder Rao P S S, Richard J et al. An Introduction to Biostatistics. A manual for students in health sciences 4th Edn 2006:86-160.

[7]. Suresh K.P. and Chandrasekhar S. Sample Size estimation and Power analysis for Clinical research studies. Journal Human Reproduction Science. 2012;5(1):7-13.

[8]. Hwang Y, Lee KH. Study on the Korean Adult Cranial Capacity. Journal of Korean Medical Science, 1995;10(4):239-42.

[9]. Manjunath KY. Estimation of cranial volume in dissecting room cadavers. Journal anatomical society of India. 2002b;51(2):168-72s.

[10]. Acer N, Usanmaz M \& Ertekin T. Estimation of cranial capacity in 17-26 year old university students. Int. J. Morp. 2007;25(1):99-102.

[11]. Gohiya VK, Shrivastava S and Gohiya S. Estimation of Cranial Capacity in 20-25 Year Old Population of Madhya Pradhesh, a State of India. Int. J. Morphl. 2010;28(4):1211-14.

[12]. MB Maina, YC Shapu, SH Garba, MA Muhammad, AM Garba, AU Yaro, Et al. Assessments of Cranial Capacities in a North-Eastern Adult Nigerian Population. Journal of Applied Sciences. 2011;2662-65.

13]. Ilayperuma Et al. Cranial capacity in an adult Sri Lankan population: Sexual dimorphism and ethnic diversity. Int. J. Morphol. 2011;29(2):479-84.

[14]. Murli Lalwani Et al. Sex identification from Cranial Capacity of Adult Human Skulls. J Indian Acad Forensic Med. April-June 2012;34(2):0971-0973.

[15]. Sadakat Ali, AP Sinha, SL Jethani, RK Rohatgi, K Anamika. Study of Cranial Capacity of Adult North Indian Human Skulls \& its Sexual Dimorphism. International Journal of Scientific case Study.2014; 1(5):29-31. 